\title{
Transformasi Nilai-Nilai Keagamaan Pada Masyarakat Asal Suku Dayak Di Banua Ampat Kabupaten Tapin
}

Oleh: Amalia dan Ahmad Gazali

\begin{abstract}
Abstrak
Pokok permasalahan penelitian ini adalah bagaimana transformasi nilai-nilai keagamaan serta bagaimana pembinaan keagamaan pada masyarakat asal suku Dayak di Banua Ampat Kabupaten Tapin. Penelitian ini bertujuan untuk mengetahui transformasi nilai-nilai keagamaan serta pembinaan keagamaan pada masyarakat asal suku Dayak di Banua Ampat Kabupaten Tapin.

Subjek dalam penelitian ini yakni: Masyarakat, Tokoh Masyarakat, Sejarahwan Banjar, Tokoh Agama, Kepala Desa, Camat, Serta Kepala Bidang Seni Dan Budaya Disporabudpar Kabupaten Tapin.

Objek penelitian adalah transformasi nilainilai keagamaan dari tradisi-tradisi yang dilaksanakan secara turun temurun serta pembinaan keagamaan pada masyarakat asal suku Dayak di Banua Ampat Kabupaten Tapin.

Teknik pengumpulan data yakni: Observasi, Interview, Dan Dokumenter. Kemudian data diolah melahi proses koleksi data, klarifikasi data, editing, serta interpretasi data. selanjutnya dianalisis menggunakan metode kualitatif deskriptif.

Berdasarkan hasil penelitian, transformasi nilai-nilai keagamaan pada masyarakat asal suku Dayak di Banua Ampat sudah banyak dipengaruhi dan mengandung ajaran agama Islam. Hal tersebut bisa terlihat dari banyaknya tradisi yang dilaksanakan masyarakat hanya semata-mata demi meningkatkan silaturrahmi, ikhtiar, serta keimanan kepada Allah sut.

Pembinaan keagamaan bisa terlihat dari rutinnya pengajian agama seperti baca tulis Alquran, ceramah agama, serta kegiatan masyarakat yang bersifat keagamaan seperti arisan Ibu-ibu, maulid habsyi, dan yasinan.
\end{abstract}

Kata Kunci: Transformasi, Keagaamaan, Dayak

\section{A. Pendahuluan}

Banua Ampat adalah bekas distrik (kawedanan) yang merupakan bagian dari wilayah administratif Onderafdeeling Banua Ampat dan Margasari pada zaman kolonial Hindia Belanda dahulu. Distrik Banua Ampat pernah dipimpin oleh Kepala Distrik (districhoofd) yaitu Kiai Kasuma Wira Negara (Distrik Banua Empat : 2012). Banua Ampat terdiri atas empat banua yaitu:

a. Banua Padang, (sekarang kecamatan Bungur, Tapin)

b. Banua Halat, (sekarang kecamatan Tapin Utara, Tapin)

c. Banua Parigi dan Banua Gadung, (sekarang kecamatan Bakarangan, Tapin).

Sekitar abad ke-17 Masehi Desa Banua

Padang, Banua Halat, Banua Parigi, Banua Gadung lebih dikenal dengan sebutan Banua Ampat. Wilayah Banua Ampat adalah salah satu kawasan teritorial kerajaan Banjar yang berpusat di Martapura Ipit Gandamana, 2007 : 45)

Suku Banjar yang mendiami wilayah bekas distrik ini disebut Orang Rantau (Bubuhan Rantau), sedangkan suku Dayaknya disebut Dayak Tapin atau Dayak Harakit atau Dayak Bukit Piani, bagian dari Suku Dayak Meratus karena pada awal abad XVII terjadi pemisahan penduduk yang menganut agama Islam dengan mereka yang menolak Islam. Pemukiman ini disebut Banua Halat, atau kampung pembatas antara yang beragama Islam dengan mereka yang menolak agama Islam. Yang menolak agama Islam berpindah ke hulu sungai Tapin dan menjadi penduduk suku Dayak Bukit atau Urang Bukit ( A. Gazali Usman, 2007: 27). Sebelum melakukan perpindahan agama, tentu mereka masih melaksanakan tradisi-tradisi yang diturunkan dari kepercayaan mereka terdahulu, 
penulis tertarik untuk meneliti sejarah asal usul orang Banua Ampat, bagaimana masuknya Islam, perubahan nilai-nilai keagamaan, serta keagamaan mereka sekarang dengan melihat tradisi mereka apakah sudah banyak dimasuki nilai-nilai agama Islam atau masih sedikit, banyak tradisi yang selalu digelar oleh masyarakat asal suku Dayak di Banua Ampat, salah satu tradisi yang sangat berkembang adalah tradisi Baayun Anak dahulu atau Baayun Maulud sekarang, dahulu orang-orang yang masih menganut kepercayaan Animisme dan menempati desa Banua Halat menamakan tradisi tersebut dengan tradisi Batapung Tawar yaitu tradisi penyerahan sang bayi kepada ibunya oleh seorang bidan yang membantu kelahiran si bayi sampai berumur beberapa hari atau biasanya 40 hari. Tradisi tersebut dilaksanakan sebagai ungkapan rasa syukur kepada Sang Pencipta atas keselamatan kelahiran bayi dan sebagai tanda terima kasih kepada bidan yang telah membantu sang ibu dalam proses kelahiran bayi mulai dari mengandung sampai melahirkan. Sekarang tradisi tersebut sudah mengalami akulturasi dan transformasi menyesuaikan dengan ajaran agama Islam misalnya tradisi tersebut sekarang dilaksanakan bersamaan dengan hari kelahiran Nabi Muhammad saw. dan acaranya ditambah dengan maulid habsyi demi kecintaan kepada Nabi Muhammad saw. serta memperkenalkan anak sejak dini akan mesjid sebagai tempat ibadah umat muslim.

Berkenaan dengan hal tersebut di atas, dilakukan penelitian untuk mengetahui nilainilai keagamaan serta upaya pembinaan keagamaan yang ada pada masyarakat asal suku Dayak di Banua Ampat Kabupaten Tapin. Maka dari itu penulis tertarik untuk mengadakan penelitian yang dituangkan dalam sebuah karya ilmiah berbentuk skripsi dengan judul:

Transformasi Nilai-Nilai Keagamaan Pada Masyarakat Asal Suku Dayak Di Banua Ampat Kabupaten Tapin

\section{B. Tujuan Penelitian}

Berdasarkan perumusan masalah yang dikemukakan di atas, maka penelitian ini bertujuan untuk mengetahui: a. Transformasi nilai-nilai keagamaan pada masyarakat asal suku Dayak di Banua Ampat Kabupaten Tapin.

b. Upaya pembinaan keagamaan masyarakat asal suku Dayak di Banua Ampat Kabupaten Tapin.

\section{Penyajian Data}

Berdasarkan hasil penelitian yang penulis laksanakan, maka didapat data sebagai berikut:

\section{1). Transformasi Nilai-Nilai Keagamaan Pada Masyarakat Asal Suku Dayak di Banua Ampat}

Transformasi nilai - nilai keagamaan bisa dilihat dari upacara atau tradisi yang menjadi adat istiadat pada masyarakat Banua Ampat, baik tranformasi dari prasejarah masyarakat atau sebelum masuk ajaran Islam dengan yang sudah dimasuki ajaran Islam ataupun transformasi yang terjadi dahulu dan sekarang meskipun masyarakatnya sudah memeluk Islam.

\section{a. Tradisi Pertanian (Baarian)}

Baarian merupakan sebuah bentuk kearifan lokal. Biasanya Baarian dilakukan saat prosesi batanam (bertanam padi) dan mangatam (memanen padi). Prosesi ini dilakukan bergantian dari satu sawah ke sawah yang lain, milik petani yang ikut Baarian. Sawah yang didahulukan digarap adalah sawah mereka yang sudah siap.

\section{b. Mendirikan Rumah (Batajak Rumah}

Dahulu di Desa Gadung, mendirikan rumah masih dilakukan secara bergotong royong oleh seluruh warga di kampung, terutama pada saat memasang tongkat dan mendirikan tiang, marambit hatop, sampai memasang rumbia. Selanjutnya pekerjaan itu diselesaikan oleh para tukang rumah dan diberi upah.

Rumah yang baik adalah rumah yang menghadap ke matahari terbit/Timur, karena menurut mereka parajakian (mudah mendapatkan rezeki), namun pada umumnya rumah sering menghadap ke jalan.

\section{c. Tradisi Perkawinan}

Bila ada seorang lelaki yang hendak kawin dengan seorang perempuan, maka terlebih dahulu keluarga dari pihak laki-laki tersebut bertanya kepada pihak keluarga perempuan yang diinginkannya. Pertama-tama keluarga laki-laki menanyakan kepada pihak 
keluarga perempuan apakah perempuan tersebut sudah ada yang mengikat atau belum. Bila si perempuan tersebut belum ada yang meminang, maka pihak keluarga laki-laki bisa mengutarakan niatnya untuk badatang (melamar).

\section{d. Tradisi Mandi-Mandi}

1) Mandi Pengantin (Badudus)

Penyelenggaraan Badudus dilaksanakan oleh kedua pengantin. Dalam acara ini disediakan sesaji 41 macam kue dan minyak likat baburih (bunga-bungaan yang dimasak dengan minyak kelapa dan lilin serta ditambah dengan minyak wangi).

Tradisi Badudus ini biasanya mempelai wanita memakai tapih bahalai (sarung panjang) ketika dimandikan, dan mempelai laki-lakinya juga memakai tapih (sarung), biasanya dilaksanakan pada waktu pagi hari atau sore hari sehari sebelum resepsi pernikahan dilaksanakan, namun di Desa Parigi ini masyarakat tidak melakukan ritual bapapay (air tawar yang dicampur dengan berbagai macam kembang lahu mayang pinang dicelupkan ke air tersebut dan dipercikkan ke kepala si pengantin), kecuali jika si pengantin merupakan turunan harus melaksanakan ritual bapapay.

Lain lagi halnya di Desa Gadung, di Desa ini ritual acara bamandi-mandi pengantin lebih panjang. Namun yang melaksanakan tradisi ini hanya keturunan-keturunan saja. Biasanya Kedua calon pengantin dimandikan bersamasama tetapi bisa juga terpisah. Kedua mempelai juga harus memakai sarung di saat prosesi Badudus dilakukan. Calon pengantin duduk di atas tapih yang di taruh di atas lantai lalu para tetuha kampung memandikan mereka diiringi dengan mantra-mantra sebagai doa, setelah itu pengantin lalu di papay, berupa minyak likat, 41 macam kembang tetapi bisa juga kurang dari 41 macam, beserta mayang. kemudian selesai dimandikan, para tetuha kampung memecahkan sebiji kelapa di atas kepala calon pengantin supaya air kelapa menyirami kepala beserta badan si calon pengantin.

2) Mandi Hamil Tujuh Bulan

Sama halnya dengan mandi pengantin, mandi tujuh bulan juga dilaksanakan secara turun temurun oleh para turunannya saja. Adapun mandi pengantin itu dilaksanakan sebelum melaksanakan acara pernikahan, sedangkan mandi tujuh bulan itu dilaksanakan pada saat wanita hamil kurang lebih tujuh bulan usia kandungannya. Sebagian masyarakat di Desa Banua Halat menyebutnya dengan mandi Badua umur karena apabila usia kandungan sudah mencapai tujuh bulan, maka bayi di dalam perut sudah bernyawa dan sudah dikatakan ada umurnya.

Ada juga yang mengatakan mandi mandi batian yaitu mandi-mandi pada saat wanita mengandung. Wanita yang hamil pertama kali (tian mandaring) harus di- upacara mandi -kan, keharusan tersebut karena turun temurun baik dari kedua orang tuanya ataupun salah satu dari orang tuanya. Konon katanya, jika tidak melaksanakan tradisi mandi-mandi batian tersebut, maka wanita yang hamil dan bayinya di dalam perut kelak akan menderita karena ada yang memingit.

Dahulu perawatan waktu melahirkan diserahkan kepada bidan kampung sedangkan sekarang orang-orang cenderung melahirkan kerumah sakit. Selain itu sebelum melahirkan, biasanya keluarga memasang tali haduk dan menanam jariangau. Hal tersebut menurut warga supaya tidak dimakan kuyang (Hantu jadi-jadian yang tidak memiliki badan, hanya kepalanya dengan ususnya), karena menurut mereka kuyang takut dengan benda-benda tersebut.

Pantangan-pantangan bagi orang yang hamil, yakni:

a. Bagi sang suami tidak boleh menyembelih ayam, dan bagi istrinya tidak boleh memotong-motong ayam, nanti fisik anak bisa cacat.

b. Jangan membelah puntong, nanti anak bisa sumbing.

c. Jangan minum air kelapa, nanti sulit melahirkan.

d. Jangan keluar rumah ketika hari sudah senja, nanti keciuman hantu baranak (orang halus).

Pantangan-pantangan bagi orang yang sudah melahirkan, yakni:

a. Jangan makan ikan tauman, bisa barahi (anak yang sudah lahir kemudian mati, begitu seterusnya).

b. Jangan makan-makanan yang berlemak, nanti tidak kering paranakan (rahim atau perut). 
Pantangan merupakan larangan bagi masyarakat yang biasa disebut dengan pamali. Pamali menurut masyarakat yaitu "peraturan masyarakat lingkungan" yang harus ditaati dan sudah merupakan hal-hal yang tidak diperbolehkan oleh nenek moyang. Pamali adalah hukum atau peraturan yang tidak tertulis di masyarakat, apabila dilanggar akan mendapatkan kemudaratan bagi yang melanggar.

3) Mandi Bahalat

Mandi Bahalat adalah mandi untuk mehalati (menghalangi) diri supaya tidak terkena penyakit atau terkena benci dari orang lain dan diberikan keselamatan. Mandi Bahalat ini biasanya dilakukan seseorang sebelum dia pergi merantau ke daerah lain.

\section{a. Kelahiran anak}

Walaupun sekarang masyarakat sudah banyak yang melahirkan di rumah sakit dan dibantu oleh seorang dokter kandungan ataupun bidan di instansi pemerintahan, namun melahirkan dengan dibantu oleh seorang bidan kampung pun masih banyak, terutama di kampung Banua Halat, Parigi, Gadung, dan Banua Padang. Bagi mereka melahirkan dengan bidan kampung itu lebih mudah, lebih cepat memangil, dan lebih murah biaya sekaligus sudah berpengalaman.

Pemotongan tali pusat dengan sembilu (batang bambu bagian luar yang diruncingkan) pun masih ada yang masih meniru walaupun sembilu adalah alat potong yang sangat tradisional dan sekarang sudah banyak alat-alat canggih di kedokteran atau rumah sakit untuk mempermudah pemotongan tali pusat. Bagi anak laki-laki yang lahir diazankan, sedangkan bagi anak perempuan diiqamatkan. Tambuni dimasukkan ke dalam kapit (wadah kecil yang terbuat dari tanah liat) disertai dengan lombok kering, bawang merah, dan sembilu. Setelah itu tambuni ditanam di bawah pohon besar atau di bawah kembang, dan ditusuk dengan paring barincung (bambu yang dipotong bagian luarnya dan seperti sudut kerucut), lalu ditinggalkan pergi.

Pantangan-pantangan bagi bayi yang baru lahir dan bagi anak-anak, yakni:

a) Sebelum usia bayi genap 40 hari dan sebelum batapung tawar, maka tidak boleh dibawa keluar rumah, nanti anak bisa panangisan (cengeng).

b) Bayi yang baru lahir, tidak boleh diberi makan, kecuali sudah berumur satu hari maka boleh diberi makan pisang, mencicipkan gula merah, kurma, madu, atau bisa juga banyu didih (air dari beras yang dimasak) bila ASI (Air Susu Ibu) belum bisa atau belum lancar keluarnya.

\section{b. Tradisi Kematian}

Sebelum masuk Islam, masyarakat memberi pertolongan kepada saudara mereka yang meninggal yakni hanya dengan memandikan, mengkafani (membungkus), dan menguburkan. Apabila mereka mengetahui bahwa ada warga yang meninggal maka mereka berdatangan ke rumah duka dengan memberikan beras, uang, ataupun bahan pokok lain sesuai dengan kemampuan. Pemberian tersebut digunakan untuk keperluan selamatan selama tiga hari.

Setelah masyarakatnya masuk Islam, maka penyelenggaraan jenazah yang wajib mereka laksanakan ada empat yaitu: memandikan, mengkafani, menyalatkan, dan menguburkan.

Meskipun boleh ditambah lagi penyelenggaraannya dengan hal-hal lain yang dianjurkan namun hukumnya Sunat saja seperti mewudukan.

Biasanya para tetangga dan keluarga berdatangan ke rumah si mayit sebagai tanda berduka cita. Tidak hanya itu, mereka juga membawakan beras dan uang untuk membantu keluarga si mayit. Mereka juga membacakan surah Yasin dan Fatihah Empat (Surah Al-Fatihah, Al-Ikhlas, An-Nass, Al-Alaq) untuk menghadiahi si mayit.

Bagi orang yang men-yembahyang- kan diberi amplop yang berisi uang berkisar antara Rp. 5.000,00 sampai Rp. 10.000,00, tergantung dari kemampuan ahlil mayit.

Dahulu masyarakat kampung tidak mengenal budaya amplop karena di setiap ada warganya yang meninggal dunia maka semua warga kampung bisa me-nyembahyangkan-nya atau bisa mencapai 40 orang. Namun sekarang budaya amplop sudah menjadi kebiasaan masyarakat sekarang termasuk masyarakat di Banua Ampat, karena sedikit banyaknya mereka sudah berbaur dengan budaya kota 
yakni mereka sibuk dengan pekerjaan mereka masing-masing.

\section{c. Tradisi Pengobatan}

Orang yang diganang (dikenang) dan dirawa (disapa) datu (arwah orang mati) atau orang halus maka seluruh tubuhnya menjadi panas, atau bisa juga kepala panas dan kaki dingin, sebelah kaki dan tangannya panas dan sebelah lainnya dingin. Sakit ini biasanya dinamakan Kapidaraan atau Katumbuhan. Datu (arwah orang mati) itu bisa arwah dari orang tua si anak yang baru meninggal atau bisa juga makhluk halus lain. Sakit ini bisa diderita oleh anak-anak, remaja, dan orang tua, namun yang paling banyak diderita oleh anak-anak karena menurut masyarakat anak-anak itu bisa melihat makhluk-makhluk halus dan mereka masih sedikit dosa. Pengobatan sakit Kapidaraan atau Katumbuhan ini biasanya dibantu oleh orang yang ahlinya dan keturunan, namun sekarang yang membantu pengobatannya diserahkan kepada seorang alim agama. Adapun cara pengobatan umumnya yakni mengoleskan hasil ulekan Janar (kunyit), kapur, dan beras ke dahi orang yang sakit kemudian dibacakan do'a Selamat, dan bisa juga orang alim memberikan sebotol air putih yang sudah diberi bacaan. Sakit Kapidaraan atau Katumbuhan ini bisa dihindari, yaitu bagi anak-anak tidak diperbolehkan melintas atau bermain-main disekitar areal pekuburan, supaya tidak disapa oleh arwah orang mati.

\section{d. Tradisi Kuda Gepang}

1. Sejarah Tradisi Kuda Gepang

Orang-orang Jawa membawa tradisi kuda gepang, pertama-tama ke Desa Barikin, lahu ke Desa Sungai Rutas, lalu ke Banua Ampat dahulu dan yang sekarang dinakaman Kabupaten Tapin, dan tradisi itu menetap di Desa Parigi yang sekarang menjadi wilayah di Kecamatan Bakarangan.

2. Alur Cerita

Kuda Gepang di Desa parigi Kecamatan Bakarangan bernama "Kuda Gepang Raden Sanjaya". Para pemain yang memainkan tradisi Kuda Gepang ini biasanya menyuguhkan sebuah cerita, cerita itu disajikan dalam beberapa babak. Ceritanya adalah sebagai berikut:

- Babak pertama: Musik panting dimainkan sebelum pengantin datang, musik panting tersebut diiringi oleh 5 sampai 6 buah lagu, lagunya berubah-ubah. Lalu Kuda Gepang bermain-main setelah itu anakanak turun dalam lakon wayang.

- Babak kedua: dua orang Patih Raja turun. Patih Raja satu bernama Patih Raja Bandit Seriri dan Patih Raja dua bernama Sura Kapriata. Lalu datang Raja yang bernama Prabunita Praga Daya Kesuma kemudian datang anak Raja yang bernama Air Saraksa Pemuja Dewa Sakti.

- Babak ketiga: anak Raja mengutarakan isi hatinya dengan sang Raja bahwa dia ingin beristri dengan orang pegunungan Ujung Sayung pating Ruban yang bernama Aluh Kadap Diang Siur-Siur atau dipanggil denganAluh Kaganangan. Ternyata Sang Raja tidak merestui karena beliau ingin mengawinkan putranya dengan perempuan yang sama-sama anak Raja. Tetapi Air Saraksa menolak dan bersikeras ingin menikahi Aluh Kaganangan. Demi cintannya kepada Aluh Kaganangan, maka Air Saraksa tetap menemui Aluh Kaganangan, tetapi rencananya untuk menikahipun berantakan karena Aluh Kaganangan sudah memiliki suami yang bernama Anak Amban. Namun hatinya tetap keras dan memaksa Aluh Kaganangan untuk dipersunting air Saraksa. Patih Raja satu pun mengiringi anak Raja dan Aluh Kaganangan berbulan Madu. Kemudian diam-diam Suami Aluh Kaganangan dibuang oleh anak Raja. Mendengar hal tersebut, maka ibu Anak Amban mencari anaknya namun tidak bertemu, dia khawatir kalau anaknya sudah meninggal dunia. Ternyata Anak Amban masih hidup dan bertapa, merasa lama bertapa lalu Anak Amban ingin pulang ke rumah, ditengah jalan simpang empat Mardu Sekawan dia menemui ibunya dalam keadaan yang bersimbah darah. Ibunya pun meninggal dunia juga karena dibunuh oleh anak Raja. Perkawinan Anak Amban dan Aluh Kagananganpun telah dihancur oleh Air Saraksa. Ceritapun Selesai.

- Babak keempat: Acara pengusungan kedua mempelai. Satu orang Pangudaan 
mengusung satu orang mempelai pengantin.

o Setiap akhir babak dilanjutkan oleh sebuah lagu. Nuansa lagunya tergantung keinginan dari para pemain.

3). Tujuan Dilaksanakan Tradisi Kuda Gepang a) Pemenuhan Hajat

Tradisi Kuda Gepang dilaksanakan sebagai pemenuhan hajat seseorang, hajat mereka berbeda-beda namun biasanya mereka melaksanakan tradisi kuda gepang apabila anak mereka sembuh dari penyakit supaya tidak sering sakit, hajat pengantin, dan lain-lain.

1. Hajat supaya sang anak tidak sering sakit Orang tua sang anak melaksanakan tradisi Kuda Gepang apabila hajat mereka terpenuhi yaitu apabila anak mereka tidak sering sakit dan sembuh dari penyakit sekaligus sebagai ungkapan rasa syukur kepada Allah atas pemenuhan hajat mereka. Biasanya para tetuha tokoh Kuda Gepang sekaligus memberikan air yang sudah diberi mantra-mantra. Dahulu sewaktu masyarakat belum menganut ajaran Islam, maka air tersebut hanya diberi mantra tetapi setelah Islam menyebar dan seluruh pemain Kuda Gepang sudah memeluk Islam, maka air sebelum dibacakan mantra terlebih dahulu dibacakan Basmalah, mantranya tetap seperti mantra yang dahulu tidak diubah menjadi bacaan-bacaan Alquran namun hanya dimulai dengan membaca Basmalah. Penulis tidak diberitahu bacaan mantranya, sebab mantra itu memang turun temurun dan hanya boleh diketahui dan dibaca oleh tokoh pemain Kuda Gepang itu sendiri.

\section{Hajat Pengantin}

Menurut Bapak Supriadi, ketua Kuda Gepang mengatakan bahwa berdasarkan mitos yang berkembang, dahulu apabila ada sepasang kekasih yang ingin menikah dan ada orang ketiga yang ingin merusak hubungan mereka maka tokoh pemain Kuda Gepang biasanya memberi air yang sudah dibacakan mantramantra dengan maksud supaya si pengantin hidup rukun, dan bahagia tidak ada yang mengganggu kehidupan mereka. Air mantra disemburkan kepada kedua mempelai pengantin. Pemberian air mantra ini juga dimaksudkan supaya sang pengantin saat diusung tidak pingsan dan tidak kesurupan.

b) Hiburan Masyarakat
Selain sebagai pemenuhan hajat, pelaksanaan tradisi Kuda Gepang juga sebagai Karasmin atau hiburan masyarakat. Selain itu Kuda Gepang juga merupakan aset dari tradisi di Kabupaten Tapin yang dilestarikan oleh masyarakat di Desa Parigi.

Sekarang Kuda Gepang dimainkan di berbagai acara, tidak hanya di pengantin saja tetapi juga di setiap acara yang diadakan di Kabupaten Tapin seperti acara syukuran, peringatan Hari Kemerdekaan RI, Pameran Hari Jadi, dan lainlain. Tradisi ini seakan-akan tidak sakral lagi karena sudah banyak masyarakat yang menyewa pemain Kuda Gepang untuk dijadikan hiburan dan pertunjukan tradisi daerah.

\section{Upaya Pembinaan Keagamaan Masyarakat Asal Suku Dayak di Banua Ampat Kabupaten Tapin}

a. Ceramah Agama

Dalam upaya pembinaan keagamaan masyarakat, para tokoh agama rutin mengadakan kegiatan keagamaan salah satunya yakni ceramah agama, kegiatan ini merupakan kegiatan yang paling ramai jamaahnya serta dengan metode ceramah agama ini bisa mempermudah penyampaian dakwah dalam skala yang besar meskipun tokoh agama atau penceramah tidak bisa mengetahui secara keseluruhan apakah jamaahnya sudah paham dengan materi yang disampaikan atau belum paham. Di Desa Gadung tokoh yang sering mengisi ceramah agama yaitu Bapak KH. A. Zaki Mubarak dilaksanakan di mesjid Istiqomah setiap hari Minggu sehabis salat Ashar, di Desa Parigi Bapak H. Jajuli bertempat di mesjid An-Nur di Desa Tangkawang yang merupakan desa pemekaran dari Desa Parigi serta dilaksanakan setiap hari Selasa sehabis salat Ashar, di Desa Banua Halat Bapak H. A. Rijali bertempat di mesjid Al-Mukarromah dilaksanakan satu kali seminggu pada hari Jumat setelah selesai salat Subuh, dan di Desa Banua Padang Bapak H. Abu Bakar BA bertempat di Mesjid Al-Ikhlas dan dilaksanakan pada hari Minggu setelah selesai salat Subuh.

Materi yang disampaikan menyangkut seluruh aspek kehidupan dan tidak jauh dari masalah akidah, syariah, dan akhlak, yang dikaitkan dengan situasi dan kondisi kehidupan pada masa sekarang. 
Materi akidah yang disampaikan berhubungan dengan keimanan seseorang yaitu Rukun Iman: iman kepada Allah swt., MalaikatMalaikat-Nya, kitab suci, Rasul-Rasul-Nya, hari Kiamat, dan Qadha serta Qadhar-Nya.

Materi Keislaman yang disampaikan menyangkut masalah amal ibadah seseorang dalam kehidupan sehari-hari yaitu Rukun Islam: Sahadat, salat, puasa, berzakat, dan menunaikan ibadah haji bagi yang mampu. Namun materi lebih di fokuskan pada tata cara sholat yang benar. Selain itu ada juga materi mengenai tata cara bersuci atau membersihkan najis.

Materi mengenai akhlak yang disampaikan yakni bagaimana akhlak dengan Allah swt., akhlak dengan sesama manusia, dan akhlak dengan seluruh makhluk ciptaan-Nya. Akhlak dengan Allah swt., yaitu dengan harus bertakwa kepada-Nya, dan akhlak antar sesama manusia dan seluruh makhluk ciptaan-Nya yaitu dengan cara tidak saling sakit menyakiti.

Kitab yang digunakan sebagai bahan ceramah tidak menentu dan menyesuaikan dengan keadaan masyarakat setempat. Namun yang sering dipegang oleh tokoh agama atau pun para pendakwah yaitu Alquran, kitab Fiqih, Sifat 20, dan Hadis Shahih Bukhari.

b. Pengajaran Baca Tulis Alquran

Pengajaaran baca tulis Alquran rutin diadakan di Banua Ampat. Pengajaran baca tulis Alquran ini tidak hanya untuk anak-anak tetapi juga orang dewasa dan orang tua. Bapak $\mathrm{H}$. Jahuri di Desa Gadung sering mengajarkan baca tulis Alquran sehabis salat Ashar di rumah beliau sendiri, pengajaran ini untuk semua kalangan masyarakat yang ingin belajar. Di Desa Parigi, tokoh guru mengaji yakni Bapak $\mathrm{H}$. Syahrul, pengajaran Alquran dilaksanakan mulai jam 14.00 wita sampai sebelum salat Ashar dan bertempat di majelis Ali Nurdin unit 084. Di Desa Banua Padang, guru mengajinya yaitu Bapak H. Ardiansyah bertempat di rumah Beliau dan dilaksanakan setelah salat Magrib. Sedangkan di Desa Banua Halat, tidak ada pusat pengajaran Alquran, namun kebiasaan masyarakatnya mengajarkan anak-anak mereka masing-masing di rumah akan baca tulis Alquran. Di dalam pengajian tersebut yang dipelajari yakni tentang tata cara membaca dan menulis Alquran yang baik dan benar serta mempelajari masalah yang berhubungan dengan penyebutan huruf yang benar, serta membaca dengan bertajwid. Pengajaran baca tulis Alquran di tiga desa tersebut dilaksanakan rutin setiap hari serta diajarkan satu persatu atau face to face antara guru dengan murid secara bergiliran.

c. Arisan Ibu-Ibu

Arisan Ibu-ibu merupakan kegiatan masyarakat yang bersifat keagamaan. Arisan tersebut rutin dilaksanakan seminggu sekali di setiap masing-masing desa secara bergiliran dari rumah kerumah warga masyarakat yang ikut serta dalam kegiatan arisan. Kegiatan ini biasanya diisi dengan pembacaan yasin, maulid habsyi, tahlilan, pembacaan burdah, serta ceramah agama. Yasinan biasanya dipimpin oleh seorang ibu yang ditunjuk oleh Ibu-ibu yang lain pada saat kegiatan arisan itu berlangsung. Kegiatan ini merupakan kegiatan yang positif karena dapat meningkatkan rasa persaudaraan antar sesama umat muslim.

d. Pendapat tokoh agama mengenai tradisitradisi

Menurut Bapak H. Jahuri, seorang tokoh masyarakat sekaligus tokoh agama Mengatakan, bahwa Desa Gadung merupakan desa yang aman dan rukun, lebih dari $90 \%$ masyarakatnya alumni dan menuntut ilmu di Pondok Pesantren Darussalam Martapura namun tidak semua warga masyarakat bisa mengikuti kegiatan keagamaan, masyarakat Desa Gadung sebagian besar sibuk mencari nafkah dan melengkapi kebutuhan pokok, misalnya memancing ikan dan banyak masyarakat yang berasalan lelah sehingga malas untuk datang ke majelis pengajian.

Menurut Bapak H. Jajuli, seorang tokoh agama di Desa Parigi mengatakan bahwa selama membantu dalam pembinaan keagamaan masyarakat, beliau tidak memiliki hambatan karena masyarakat Desa Parigi dapat dikatakan masyarakat yang fanatik dalam beragama yakni sebagian besar selalu melaksanakan ajaran agama Islam dengan baik dilihat dari banyaknya jamaah salat di langgar, peserta maulid habsyi, jamaah pembacaan kitab, dan jamaah ceramah agama.

Adapun tradisi-tradisi yang sering dilaksanakan di Desa Parigi seperti tradisi Baarian dan tradisi seni Kuda Gepang, itu sudah 
merupakan adat istiadat di masyarakat, meskipun bukan perintah dari kitab suci Alquran namun mengandung nilai-nilai keagamaan yakni rasa saling bersatu, bergotong royong dan mempererat silaturrahmi sebagai sesama muslim, tradisi itu tidak perlu dihilangkan asalkan tidak melenceng dari ajaran agama Islam atau tidak mengandung penilaian musyrik. Selama masyarakat menganggap bahwa tradisi tersebut sebagai adat istiadat saja, dan sebagai ibadah dalam mendekatkan diri kepada Allah swt., serta demi bersilaturrahmi dan kebaikan sosial, maka tidak perlu ada pelurusan nilai-nilai keagamaan, tanpa terkecuali jika hal tersebut melenceng dan mengandung unsur musyrik misalnya masyarakat memiliki keyakinan apabila tidak melaksanakan tradisi itu maka akan mendapat musibah, bala, dan sebagainya. Hal-hal semacam itu harus diluruskan supaya tidak mengarah kepada kemusyrikan, dengan cara memberikan ceramah agama dengan materi mengenai pemahaman akidah atau keyakinan yang benar.

Menurut Bapak Hidayatullah, seorang kaum mesjid Al-Ikhlas mengatakan bahwa selama membantu dalam pembinaan keagamaan pada masyarakat yang menjadi hambatan dalam pelaksanaan kegiatan keagamaan yakni masalah logistik, namun hambatan itu bisa teratasi karena tidak sedikit warga yang menyumbang untuk kegiatankegiatan keagamaan. warga masyarakat Desa Banua Padang dapat dikatakan masyarakat yang rajin dalam mengikuti kegiatan keagamaan bila dilihat dari banyaknya jamaah sholat di Mesjid ataupun Langgar, jamaah ceramah agama, peserta maulid habsyi, dan pembacaan burdah. Sedangkan jamaah yang paling banyak yakni pada kegiatan ceramah agama.

Adapun tradisi yang sering dilaksanakan di Desa Banua Padang yakni tradisi gotong royong Batajak Rumah, itu sudah merupakan adat istiadat di masyarakat yang sudah turun temurun, meskipun sekarang gotong royong itu dilakukan tidak sepenuhnya atau tidak sampai menjadi rumah, hanya sebagian kecil saja seperti batajak tihang. Hal tersebut tentu bukan perintah dari kitab suci Alquran namun mengandung nilai-nilai keagamaan yakni rasa saling bersatu senasib sepenanggungan, bergotong royong dan mempererat silaturrahmi antar sesama manusia, tradisi itu tidak perlu dihilangkan namun perlu diluruskan apabila di dalam tradisi tersebut ada keyakinan-keyakinan yang menghubungkan keselamatan hidup manusia dengan makhluk gaib.

Menurut Bapak Rahmadi, seorang kaum mesjid Al-Mukarromah sekaligus tokoh agama mengatakan bahwa masyarakat Banua Halat Kiri beragama Islam Ahli Sunah wal Jamaah, masyarakatnya juga sangat kuat dalam beragama, hal ini bisa terlihat dari rutinnya kegiatan keagamaan yang dilaksanakan seperti ceramah agama, adapun materi yang sering diberikan menyangkut seluruh aspek kehidupan namun yang paling sering menyangkut masalah akidah, syariah, dan akhlak. Tradisi yang paling sering dilaksanakan yakni selamatan-selamatan kecil, setiap hari pasti ada orang yang datang ke mesjid Al-Mukarromah Desa Banua Halat Kiri untuk melaksanakan selamatan. Biasanya orang yang melaksanakan selamatan karena berhajat atau terkabul dari hajatnya, misalnya hajat apabila anak mereka sembuh dari penyakit, lulus sekolah, sukses kuliah, baru menikah, dan sebagainya yang datang dari berbagai kalangan mulai dari warga sekitar sampai dari luar Kalimantan Selatan.

Selamatan-selamatan kecil sudah menjadi tradisi dan mendarah daging di masyarakat serta sudah menjadi tradisi yang turun termurun karena konon masyarakat ingin minta berkah dari kekeramatan mesjid tersebut sekaligus mendatangi Datu Ujung. Selamatan di mulai dengan membacakan do'a selamat oleh penjaga mesjid, kemudian hidangan yang dihidangkan dimakan bersama dan dibagikan kepada orang-orang yang datang. Menurut Bapak Rahmadi, tradisi tersebut tidak menyalahi agama Islam karena merupakan salah satu pembinaan kepada masyarakat agar selalu berdo'a, bersyukur atas keselamatan dan hajat yang yang telah dikabulkan oleh Allah swt. sekaligus tanda terima kasih kita kepada Sang Pencipta Alam. Selamatan di mesjid juga mengenalkan anak-anak sejak dini kepada mesjid sebagai simbol dan tempat ibadah umat muslim. Begitu pula dengan tradisi besar yang diadakan di Banua Halat Kiri yakni Baayun Maulud, tradisi ini juga tidak menyalahi agama 
selama masih banyak nilai-nilai agama Islamnya, dan tradisi ini turun temurun terus dilaksanakan karena tujuannya juga sama dengan tradisi selamatan, selain itu juga dapat mempererat persaudaraan dengan warga perbukitan yakni masyarakat suku Dayak di Pegunungan Meratus Tapin sebagai tanda badangsanak.

\section{Analisis Data}

Pada abad ke-16 Islam masuk ke Banua Ampat melalui transfortasi air dan menyebar sampai ke daerah pedalaman. Salah satu jalur penyebaran Islam di Banua Ampat dimulai dari Desa Gadung karena dahulu Desa Gadung dijadikan pelabuhan kemudian ke arah hulu, ke Banua Halat, Banua Padang, dan Banua Parigi. Islam masuk secara damai dan masyarakatnya masuk Islam secara sukarela tanpa ada paksaan dari siapapun. Menurut folklore yang berkembang di masyarakat bahwa yang mempelopori masuknya Islam di Banua Ampat adalah Intingan yang biasanya disebut masyarakat dengan sebutan Datu Ujung, sedangkan yang masih menganut kepercayaan nenek moyang yang bernama Dayuhan, keduanya adalah saudara kandung kakak beradik.

Pada abad ke-17 terjadi pemisahan penduduk, bagi yang menganut agama Islam, maka tetap tinggal di Banua Halat tetapi bagi yang tetap mempertahankan kepercayaan lamanya maka berpindah ke daerah yang lebih tinggi yaitu di pegunungan Meratus Tapin. Bagi masyarakat yang bermukim di pegunungan atau di perbukitan disebut urang Bukit atau Suku Dayak Bukit. Dinamakan Banua Halat karena Banua itu artinya kampung sedangkan Halat itu artinya pembatas, jadi Banua Halat adalah kampung pembatas antara masyarakat yang masuk agama Islam dengan masyarakat yang masih menganut kepercayaan lamanya.

Asal usul orang Banua Ampat banyak yang mengatakan berasal dari masyarakat Suku Dayak bila dilihat dari prosesi kesamaan perlengkapan acara dari dua tradisi yaitu tradisi Baayun Maulud pada masyarakat Banua Halat dan tradisi Aruh Ganal pada masyarakat Suku Dayak Bukit Tapin. Namun masyarakat Banua Ampat tidak mau disebut Suku Dayak karena mereka sudah memeluk ajaran Islam dan menjadi orang Kalimantan Selatan atau orang
Banjar yang dinamakan dengan Suku Banjar karena bagi mereka sebutan untuk Suku Dayak Bukit itu merupakan saudara mereka yang masih menganut kepercayaan nenek moyangnya yang tinggal di perbukitan gunung Meratus Tapin.

\section{Analisis transformasi nilai-nilai keagamaan pada masyarakat asal suku Dayak di Banua Ampat Kabupaten Tapin}

Menurut teori dari M. Suriansyah Ideham dan kawan-kawan mengenai tradisitradisi masyarakat di dalam bukunya yang berjudul Urang Banjar dan Kebudayaannya, maka penulis dapat mengklasifikasikan tradisitradisi yang didapat di lapangan menjadi beberapa kelompok.

Menurut Bustanuddin Agus dalam bukunya yang berjudul Agama dalam Kehidupan Manusia Pengantar Antropologi Agama, aspek keagamaan itu ada 5, yakni: kepercayaan kepada kekuatan gaib, sakral, ritual, umat beragama, mistisme dan kebatinan. ${ }^{1}$ Berdasarkan teori tersebut maka penulis menghubungkan dengan tradisi-tradisi yang didapat di lapangan guna menganalisis.

\section{Analisis upaya pembinaan keagamaan pada masyarakat asal suku Dayak di Banua Ampat kabupaten Tapin}

Dalam upaya pembinaan keagamaan pada masyarakat di Banua Ampat ada beberapa metode dakwah yang dominan dipakai oleh para tokoh agama yakni metode ceramah agama, metode pendidikan dan pengajaran agama seperti baca tulis Alquran dan Kegiatan sosial masyarakat seperti arisan Ibu-ibu. Kegiatan keagamaan rutin diadakan di masing-masing desa.

Dari beberapa metode tersebut, metode ceramah agamalah yang dipakai oleh para tokoh agama di masing-masing desa, karena dengan metode tersebut para tokoh agama bisa lebih cepat dan mudah dalam menyampaikan materi dakwah dan langsung dalam skala yang besar. Tetapi tokoh agama masih belum bisa memperhatikan jamaahnya secara keseluruhan apakah materi dakwah tersebut sudah bisa dipahami oleh semua jamaah ataukah belum. Hal tersebut tentu tidak menyurutkan semangat para pendakwah, mereka tetap

\footnotetext{
${ }^{1}$ Bustanuddin Agus, op. cit., h. 60.
} 
mempertahankan metode ceramah agama mengingat dengan metode ini bisa menarik minat masyarakat untuk menghadiri kegiatan keagamaan terlihat dari banyaknya jamaah yang datang apabila ada kegiatan ceramah agama. Kegiatan keagamaan biasanya dilaksanakan di mesjid dan kegiatan kemasyarakatan yang bersifat keagamaan biasanya dilaksanakan di rumah-rumah warga.

Dominannya metode ini dipakai tidak serta merta meninggalkan metode-metode yang lain. Metode pendidikan dan pengajaran agama juga masih diterapkan, hal ini bisa dilihat dari upaya dalam memberikan pengajaran baca tulis Alquran.

Metode-metode dakwah diatas bisa juga dipakai melahui tradisi-tradisi yang dilaksanakan di masyarakat, seperti membacakan salawat Nabi dalam tradisi Baayun Maulud, Maulid Habsyi pada tradisi perkawinan, pembacaan do'a Tasmiyah pada tradisi Bapalas Bidan serta memanjatkan do'a kepada Allah swt. sebelum dan sesudah berlangsungnya tradisi. Selain itu juga pembinaan keagamaan dapat diupayakan melalui tradisi teater, seperti pada tradisi Kuda Gepang menyiratkan makna dari sebuah cerita akan nilai-nilai agama.

Adapun materi dakwah yang disampaikan menyangkut seluruh aspek kehidupan. Namun karena di Banua Ampat sangat banyak tradisi yang turun temurun, maka penyampaian materi dakwah lebih dominan kepada masalah akidah, syariah, dan akhlak, sedangkan kitab yang menjadi pedoman yakni Alquran, Hadis, kitab-kitab Fiqih, serta kitab kuning seperti sifat 20.

Masyarakat Desa Banua Halat terbilang masyarakat yang agamis dan kuat dalam tali persaudaraan. Hal tersebut bisa dibuktikan dengan selalu banyaknya jamaah yang hadir di setiap kegiatan keagamaan, begitupula dengan kegiatan kemasyarakatan seperti arisan, burdahan, tahlilan dan maulid habsyi, masyarakat yang mengikuti juga banyak, dari sana terlihat keagamisan dan keakraban masyarakatnya. Meskipun mereka juga sibuk bertani namun masih menomorsatukan keagamaan yang bisa mempertebal keimanan mereka kepada Allah swt.

\section{E. Kesimpulan}

Berdasarkan uraian-uraian yang telah dikemukakan pada bab terdahulu, maka penulis dapat menarik keKesimpulan sebagai berikut:

1. Transformasi nilai-nilai keagamaan pada tradisi masyarakat asal Suku Dayak sudah cenderung mengarah dan berkesesuaian dengan ajaran Islam meskipun banyak pengaruh dari ajaran atau kepercayaan lain sebelum masuknya ajaran Islam. Transformasi nilai-nilai keagamaan tersebut pada masyarakat asal suku Dayak di Banua Ampat dapat dilihat dari banyaknya tradisi yang mendapat transformasi nilai-nilai keagamaan yaitu: terlaksananya ajaran agama Islam, semakin mendekatkan diri kepada Allah swt., semakin mempererat tali silaturrahmi antar sesama umat beragama, serta tanda cinta kepada Rasulullah saw. Adapun tradisi-tradisi yang didapat dilapangan yakni tradisi baarian, batajak rumah, perkawinan, mandi pengantin, mandi hamil tujuh bulan, mandi bahalat, kelahiran anak, bapalas bidan-batasmiyahmaayun anak, baayun maulud, kematian, pengobatan, selamatan, serta kuda gepang.

2. Upaya pembinaan keagamaan masyarakat asal suku Dayak yang dilaksanakan oleh para tokoh agama yakni menggunakan metode ceramah agama dan metode pengajaran baca tulis Alquran. Kegiatankegiatan tersebut diisi dengan pembinaan kegamaan baik dalam aspek tauhid, fiqih, maupun akhlak.

\section{DAFTAR PUSTAKA}

Ahmad Abdullah al-Masdoosi, Ahmad, Living Religion of the World a Social Political Study, Korochi, Begun Asia Blowed Work, 1962.

Daud, Alfani, Islam dan Masyarakat Banjar, Jakarta, PT Raja Grafindo Persada, 1997.

Distrik Banua Empat-Wikipedia Bahasa Indonesia, Ensiklopedia Bebas, 03/07/2012.

Dove, Michael R., Kebudayaan Dayak Aktualisasi dan Transformasi, Jakarta, 
PT Gramedia Widiasarana Indonesia, 1994.

Gandamana, Ipik, Wajah Tapin Masa Kini, Tapin, Humas Pemkab Tapin, 2007.

Ideham, M. Suriansyah, et. al., Urang Banjar dan Kebudayaannya, Banjarmasin, Badan

Penelitian dan Pengembangan Daerah Propinsi Kalimantan Selatan dan Pustaka Banua, 2007.

Jalaluddin Al-Mahalli, Imam dan Imam Jalaluddin As-Suyuthi, Tafsir Jalalain,
Surabaya, Darul Thya kitab Arabiah, $1414 \mathrm{H}$.

Syafruddin, Imu Dakwah Sebagai Disiplin Imu, Banjarmasin, Antasari Press, 2009.

Syukir, Asmuni, Dasar-Dasar Strategi Dakwah Islam, Surabaya, A1-Ikhlas, 1983.

Usman, A. Gazali, Sejarah Berdirinya Masjid Banua Halat, Tapin, Dinas Kebudayaan dan Pariwisata Kabupaten Tapin, 2007 